\section{Shade Increases Susceptibility of Amaranthus hybridus 'Quelite' to Pythium Damping-off}

\author{
Ramsey L. Sealy, C.M. Kenerley ${ }^{2}$, and E.L. McWilliams ${ }^{3}$ \\ Texas A\&M University College Station, TX 77843
}

Additional index words. Pythium myriotylum, light level

Abstract. The effects of three light levels $\left(1403,806\right.$, and $462 \mu \mathrm{mol} \cdot \mathrm{s}^{-1} \cdot \mathrm{m}^{-2}$ on the severity of damping-off caused by Pythium myriotylum Drechsler in Amaranthus hybridus L. 'Quelite' were tested. The observed mortality $(33 \%, 69 \%$, and $81 \%$, respectively) decreased as light intensity increased. The reduction in plant growth and maturity in a shaded location is related to the observed increase in suspectibility to damping-off in such an environment.

The amount of incident radiation reaching a plant affects all of its life processes, including its response to a challenge from a disease-inciting organism. However, most studies on disease-light interactions have been performed in vitro or on detached plant parts (Benedict, 1971; Blakeman and Dickinson, 1967). Only rarely has the effect of light level on disease development been studied on intact plants under controlled environmental conditions (Benedict, 1971; Pandey and Wilcoxson, 1970; Zadoks, 1967).

The role of light level in disease development has most often been demonstrated in diseases caused by foliar pathogens. Only one study examined this interaction with a disease caused by a soil-borne pathogen (Matson and Waring, 1984). Pythium damping-off is an important disease of many cultivars of Amaranthus (National Research Council, 1984). In earlier work with screening accessions of Amaranthus for resistance to damping-off (Sealy et al., 1988), control lines seemed to suffer greater mortality under sustained cloud cover than under clear skies. Other workers have reported a similar type of variability of results in working with

Received for publication 25 Apr. 1988. We wish to thank E. Espitia Rangel, Campo Agricola Experimental, Chapingo, Mexico, for providing the seeds of A. hybridus 'Quelite'. The cost of publishing this paper was defrayed in part by the payment of page charges. Under postal regulations, this paper therefore must be hereby marked $a d$ vertisement solely to indicate this fact.

'Graduate Student (Tom Slick Fellow), Dept. of Horticultural Sciences. Present address: Dept. of Microbiology, ESB 226, UT, Austin, TX 787121095.

${ }^{2}$ Associate Professor, Dept. of Plant Pathology and Microbiology.

${ }^{3}$ Professor, Dept. of Horticultural Sciences. a Pythium- caused disease (Hausbeck et al., 1987). Texas bedding plant producers report greater problems with damping-off when there is an extended period of cloudy weather (D.C. Wilkerson, personal communication). Therefore, our purpose in this study was to examine the effect of various light intensities on the severity of pythium damping-off in Amaranthus hybridus 'Quelite'.

Seeds were obtained from the agricultural experiment station at Chapingo, Mexico. The strain of Pythium myriotylum Drechsler used in this study was isolated from a diseased amaranth seedling. Oospores were produced and quantified, and seedlings were produced as described by Sealy et al. (1988). Threeday-old amaranth seedlings in test pots (10 seedlings per pot) were challenged with 0.5 $\mathrm{ml}$ each of the oospore suspension $(5000$ oospores per seedling). In control pots, each seedling was treated with $0.5 \mathrm{ml}$ of sterile distilled water.

The experiment was conducted in a splitpilot design, with light level as the main plot and type of inoculation as the sub-plot. Average light levels used were 1403, 806, and $462 \mu \mathrm{mol} \cdot \mathrm{s}^{-1} \cdot \mathrm{m}^{-2}$. Shading was provided by neutral-density nylon cloth. At each light level, five pots of seedlings (the experimental unit) were inoculated with the fungus (test pots) and five pots served as controls. The study was performed three times between 5 May and 15 Aug. 1987, and each study was treated as a replicate.

The number of dead seedlings in each pot was counted daily for 6 days, and the percent mortality for each inoculated pot was calculated. Fresh and dry weights of the roots and shoots of 25 randomly selected control seedlings from each light treatment were recorded at the end of each test. Seedlings were washed in distilled water, separated at the crown, and fresh and dry (24 hr at $75 \mathrm{C})$ weights were determined.

Ambient temperature and humidity in the greenhouse were recorded using a hygrothermograph; air and soil temperatures for each light treatment were measured daily using a mercury thermometer. Light levels were recorded daily at noon using a LI-COR radiometer (model LI-185, Lincoln, Neb.). Light levels among replicates ranged from 1053 to $1587 \mu \mathrm{mol} \cdot \mathrm{s}^{-1} \cdot \mathrm{m}^{-2}$ under full light, from 633 to $835 \mu \mathrm{mol} \cdot \mathrm{s}^{-1} \cdot \mathrm{m}^{-2}$ under intermediate shading, and from 348 to $540 \mu \mathrm{mol} \cdot \mathrm{s}^{-1} \cdot \mathrm{m}^{-2}$ under greatest shading.

Results were analyzed using the SAS regression program (SAS Institute, Inc.). Since disease development was expressed as a percentage, the arcsin of the percentages was regressed against light level. However, since these results were so similar to those for mortality percentages, percentages are reported for ease of interpretation.

The degree of severity of damping-off increased as light level decreased; mortalities were $33 \%, 69 \%$, and $81 \%$ for light levels of 1403,806 , and $462 \mu \mathrm{mol} \cdot \mathrm{s}^{-1} \cdot \mathrm{m}^{-2}$, respectively. A significant relationship existed between light level and percent mortality $\left(R^{2}=\right.$ $0.84 ; P=0.017$ ) (Fig. 1). None of the plants died among the controls.

The onset of mortality began 1 day earlier (the third after treatment) in the shaded treatments than in the full available light treatment $\left(1403 \mu \mathrm{mol} \cdot \mathrm{s}^{-1} \cdot \mathrm{m}^{-2}\right)$. However, no

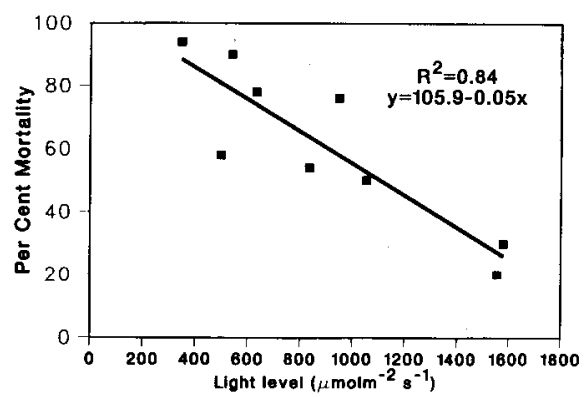

Fig. 1. Mortality (\%) for seedlings of Amaranthus hybridus 'Quelite' challenged by Pythium myriotylum regressed against light levels. Squares represent the means of five observations each.

Table 1. Partition of treatment sum of squares for mortality of Amaranthus hybridus 'Quelite' when challenged by Pythium myriotylum. Light level is the main treatment and temperature is the covariate.

\begin{tabular}{lcc}
\hline \hline $\begin{array}{l}\text { Source of } \\
\text { variation }\end{array}$ & $\begin{array}{r}\text { Sum of } \\
\text { squares }\end{array}$ & $\begin{array}{r}\text { Percent } \\
\text { of total }\end{array}$ \\
\hline Light & 4083.2 & 93.0 \\
Temperature & 292.3 & 6.6 \\
Temperature $\times$ light & 16.6 & 0.4 \\
\hline
\end{tabular}


difference in the rate of disease progression was observed between the two shaded treatments $\left(806\right.$ and $\left.462 \mu \mathrm{mol} \cdot \mathrm{s}^{-1} \cdot \mathrm{m}^{-2}\right)$.

Daily noon air temperatures ranged $8 \mathrm{C}$ among the replicates (31 to 39C), but the range among treatments within replicates did not exceed $2 \mathrm{C}$. Thus, temperature, either as a covariate or in interaction with light level, did not significantly affect disease severity (Table 1). Since all pots were kept at the same moisture level throughout the experiment, it is unlikely that potting medium moisture or aeration had a significant effect on disease severity.

With decreased light, seedlings of $A$. hybridus 'Quelite' exhibited a reduction in growth. Dry weights of control (uninoculated) seedlings were $0.469 \pm 0.004,0.188$ \pm 0.03 , and $0.098 \pm 0.02$ at light levels of 1403,806 , and $462 \mu \mathrm{mol} \cdot \mathrm{s}^{-1} \cdot \mathrm{m}^{-2}$, respectively. Control seedlings grown in full available light were vigorous, with the second set of true leaves expanded, while those from the heaviest shade treatment were extremely spindly, with only a partially expanded set of true leaves: The reduction in growth and maturity due to low light levels likely is involved in the increased susceptibility of the seedlings to damping-off. Seedlings of most plants susceptible to pythium damping-off become less susceptible as they mature and their cell walls become lignified (Agrios, 1988). Even the rather moderate shading in the intermediate light level of this study (806 $\mu \mathrm{mol} \cdot \mathrm{s}^{-1} \cdot \mathrm{m}^{-2}$ ) of $A$. hybridus drastically reduced seedling growth, accelerated the rate of disease development, and more than doubled its susceptibility to pythium dampingoff. Thus, supplemental lighting during periods of sustained cloudiness may be an effective means of reducing or controlling pythium damping-off in bedding plant and vegetable transplant production.

\section{Literature Cited}

Agrios, G.N. 1988. Plant pathology. 3rd ed. Academic, New York. p. 177, 207, 209-211.

Benedict, W.G. 1971. Differential effect of light intensity on the infection of wheat by Septoria tritici Desm. under controlled environmental conditions. Physiol. Plant Pathol. 1:55-66.

Blakeman, J.P. and C.H. Dickinson. 1967. The effect of ultraviolet and visible light on infection of host leaf tissue by four species of $A s$ cochyta. Trans. Brit. Mycol. Soc. 50:385-396.

Hausbeck, M.K., C.T. Stephens, and R.D. Heins. 1987. Variation in resistance of geranium to Pythium ultimum in the presence or absence of silver thiosulphate. HortScience 22:940-944.

Matson, P.A. and R.H. Waring. 1984. Effects of nutrient and light limitation on mountain hemlock: Susceptibility to laminated root rot. Ecology 65:1517-1524.

National Research Council. 1984. Amaranth: Modem prospects for an ancient crop. National Academy Press, Natl. Acad. Sci., Washington, D.C.

Pandey, M.C. and R.D. Wilcoxson. 1970. The effect of light and physiologic races on Leptosphaerulina leaf spot of alfalfa and selection for resistance. Phytopathology 60:1456-1462.

SAS Institute, Inc. 1985. SAS user's guide: Statistics. Version 5. SAS Inst., Inc., Cary, N.C.

Sealy, R.L., C.M. Kenerley, and E.L. Mc-
Williams. 1988. Evaluation of Amaranthus accessions for resistance to damping-off by Pythium myriotylum. Plant Dis. 72:985-989.
Zadoks, J.C. 1967. An inhibitory effect of light on the infection by brown leaf rust of wheat. Netherlands J. Plant Pathol. 73:52-54. 